"Przegląd Prawa Konstytucyjnego" Nr 1 (13)/2013 ------

\title{
Sprawozdanie
}

\section{Zjazd Katedr i Zakładów Prawa Konstytucyjnego nt.: Aktualne problemy reform konstytucyjnych, Augustów, 10-12 maja 2012 r.}

Przywilej organizowania 54. Zjazdu Katedr i Zakładów Prawa Konstytucyjnego przypadł Katedrze Prawa Konstytucyjnego Wydziału Prawa Uniwersytetu w Białymstoku. Ośrodek białostocki po raz drugi gościł przedstawicieli polskiej nauki prawa konstytucyjnego (poprzednio w Białowieży w 1995 r.). Tym razem jako miejsce spotkania wybrano Augustów (Hotel „Warszawa”). Tematykę Zjazdu Katedr stanowiły Aktualne problemy reform konstytucyjnych.

Uczestnikami Zjazdu byli w szczególności przedstawiciele nauki prawa konstytucyjnego, ustrojoznawcy, teoretycy państwa i prawa (kierownictwo i pracownicy Katedr i Zakładów Prawa Konstytucyjnego publicznych i niepublicznych szkół wyższych, Instytutu Nauk Prawnych Polskiej Akademii Nauk). W tym gronie, co trzeba odnotować, nie zabrakło zasłużonych dla polskiego konstytucjonalizmu postaci, m.in. prof. zw. dr hab. Marii Kruk-Jarosz, prof. zw. dr. hab. Wiesława Skrzydły i prof. zw. dr. hab. Pawła Sarneckiego. Obecni byli także: prezes Trybunału Konstytucyjnego prof. zw. dr hab. Andrzej Rzepliński, a także były prezes Trybunału, dr Bohdan Zdziennicki, sędziowie Trybunału Konstytucyjnego i Sądu Najwyższego. Przybyły także osoby zawodowo związane i zainteresowane problematyką konstytucyjno-ustrojową, afiliowane przy Kancelarii Prezydenta, Kancelarii Sejmu, Kancelarii Senatu, Trybunale Konstytucyjnym, Najwyższej Izbie Kontroli, Biurze Rzecznika Prawa Obywatelskich. Warto też podkreślić, iż relatywnie dużą grupę uczestników Zjazdu stanowili doktoranci reprezentujący liczne ośrodki naukowe. 
Na początku Zjazdu minutą ciszy uczczono pamięć prof. zw. dr. hab. Wojciecha Sokolewicza oraz tragicznie zmarłej dr Leny Kondratiewej-Bryzik. Wspomnienie wygłosił prof. zw. dr hab. Jan Wawrzyniak. Podkreślił on, że prof. W. Sokolewicz, sędzia Trybunału Konstytucyjnego w stanie spoczynku, był niezwykle zasłużony dla polskiego ustrojoznawstwa, był wychowawcą wielu pokoleń badaczy, a przy tym także dla wszystkich. Dr Lena Kondratiewa-Bryzik z Poznańskiego Centrum Praw Człowieka Instytutu Nauk Prawnych PAN była osobą lubianą i powszechnie cenioną w gronie konstytucjonalistów.

I.

Uroczystego otwarcia 54. Zjazdu dokonał kierownik białostockiej Katedry Prawa Konstytucyjnego, prof. UwB dr hab. Stanisław Bożyk. Witając przybyłych uczestników, profesor wyraził radość ze wspólnego spotkania i przywołał także wspomnienia związane z białowieskim Zjazdem w 1995 r. Profesor wspomniał także o tych, którzy z różnych ważnych przyczyn nie mogli wziąć udziału w spotkaniu.

Następnie głos zabrał Jego Magnificencja Rektor Uniwersytetu w Białymstoku prof. dr hab. Jerzy Nikitorowicz. W wystąpieniu swoim podkreślił przełom, jaki dla uczelni był moment jej usamodzielnienia się (1997 r.), który nadto zbiegł się w czasie z uchwaleniem i wejściem w życie Konstytucji RP. Profesor podkreślił między innymi rolę Uniwersytetu w Białymstoku w zakresie promocji regionu, jak i wypełniania szczególnej misji, jaką jest budowanie więzi kulturowej (kontakty z Uniwersytetem w Grodnie; filia Wydziału Prawa UwB w Wilnie). Profesor, dziękując uczestnikom Zjazdu za przybycie, życzył przyjemnych i konstruktywnych obrad.

W imieniu dziekana Wydziału Prawa UwB prof. dr hab. Leonarda Etela Uczestników powitał prodziekan dr Jarosław Matwiejuk, który wyraził radość z organizacji Zjazdu i przekonanie o istotnych, praktycznych rezultatach spotkania.

Uroczystym punktem pierwszego dnia Zjazdu Katedr było wręczenie prof. zw. dr. hab. Marianowi Grzybowskiemu dedykowanej mu księgi zatytułowanej Konstytucja. Ustrój polityczny. System organów państwowych 
(Wyd. Temida 2, Białystok 2010 r.). Księga jest zbiorem prac ofiarowanych Profesorowi przede wszystkim przez pracowników i doktorantów Katedry Prawa Konstytucyjnego oraz Katedry Teorii Państwa i Prawa Wydziału Prawa UwB. W latach 2004-2010 prof. Marian Grzybowski, wybitny znawca problematyki konstytucyjno-ustrojowej, sędzia Trybunału Konstytucyjnego w stanie spoczynku, był związany z Wydziałem Prawa UwB, w latach 2005-2010 kierował tutejszą Katedrą Prawa Konstytucyjnego.

II.

Tematem pierwszej sesji Zjazdu była Problematyka zmian $w$ Konstytucji $R P$ z 1997 roku, a jej moderatorem był prof. zw. dr hab. Marian Grzybowski (Uniwersytet Jagielloński w Krakowie). Jeden z referatów zaprezentował prof. dr hab. Adam Jamróz, kierownik Katedry Teorii Państwa i Prawa na Wydziale Prawa UwB. W swoim wystąpieniu (Status konstytucyjny Prezydenta RP w funkcji określonych $w$ art. 126 Konstytucji. Propozycje wykładni) profesor wskazał teoretyczne podstawy działalności prezydenta RP. Przede wszystkim stwierdził on, że materiałem normatywnym, na gruncie którego można konstruować podstawę normatywną działań prezydenta mogą niekiedy być nie tylko konstytucyjne przepisy prawne określające konkretne kompetencje, ale także inne przepisy prawne, a nawet inne wypowiedzi konstytucyjne (np. przepisy z art. 126). Profesor sformułował tezę, niekiedy rzeczywiste normy kompetencyjne mogą wynikać z wykładni systemowej, a także funkcjonalnej, a nie tylko z wykładni językowej kompetencji określonych w konkretnych przepisach konstytucyjnych. Z art. 126 Konstytucji, na którym się skoncentrował, wynikają funkcje działalności prezydenta RP.

W referacie wygłoszonym przez prof. zw. dr. hab. Bogusława Banaszaka (Uniwersytet Wrocławski), zatytułowanym Jakie zmiany w Konstytucji RP sq potrzebne?, Autor poświęcił uwagę analizie tych obszarów materii konstytucyjnej, które wymagają najpilniejszych zmian. Najistotniejszym z tych obszarów - zdaniem profesora - jest tzw. problematyka europejska, a w szczególności: wprowadzenie konstytucyjnej normy regulującej kwestię praktyki implementacyjnej prawa UE; konieczność jednoznacznego, pozytywnego rozstrzygnięcia kognicji Trybunału Konstytucyjnego obejmującej kontro- 
lę aktów prawa wtórnego Unii Europejskiej w trybie skargi konstytucyjnej; ukształtowanie w Konstytucji zasad współdziałania naczelnych organów państwa w sprawach związanych z członkostwem Rzeczypospolitej Polskiej w UE; określenie szczególnego trybu wystąpienia Rzeczypospolitej Polskiej z UE oraz pozycji ustrojowej Narodowego Banku Polskiego i Rady Polityki Pieniężnej po przystąpieniu Polski do tzw. strefy euro. Prof. B. Banaszak postulował także konstytucjonalizację niektórych elementów zasady społeczeństwa obywatelskiego oraz prokuratury. Wskazał na konieczność skoncentrowania rozproszonych unormowań zagadnień prawa wyborczego, jak też m.in. na potrzebę konstytucjonalizacji Państwowej Komisji Wyborczej. Profesor B. Banaszak pozytywnie odniósł się natomiast do postulatów likwidacji sądów wojskowych.

Kolejny referat w tej części Zjazdu Katedr wygłosił prof. UW dr hab. Ryszard Chruściak (Uniwersytet Warszawski). W swoim referacie pt. Projekty zmian $w$ Konstytucji RP profesor wnikliwie przeanalizował wszystkie formalne projekty zmian obowiązującej Konstytucji (od 1997 r. do 2012 r.), które zawarte były w drukach sejmowych. Usystematyzował wszystkie niezbędne informacje o tych projektach według następujących kryteriów: okresu złożenia projektu; częstotliwości i ogólnych przesłanek zmian; zakresu i materii projektów; problematyki zgodności projektów z prawem; podmiotów wykonujących inicjatywę $\mathrm{w}$ omawianym zakresie; uzasadnień projektów; stanowisk i opinii do projektów, formułowanych przez uprawnione podmioty; procedury legislacyjnej projektów oraz końcowych rezultatów prac ustawodawczych.

W ożywionej dyskusji podniesiono ważkie kwestie pozostające w obszarze materii omawianych przez referentów. Zwrócono zwłaszcza uwagę na problem normatywności tych kompetencji prezydenta RP, które nie są wprost wyartykułowane w przepisach Konstytucji. Poruszano też kwestie konieczności dokonywania zmian w Konstytucji RP i zakresu ewentualnych zmian.

Prof. zw. dr hab. Jacek Sobczak (Szkoła Wyższa Psychologii Społecznej w Warszawie, sędzia Sądu Najwyższego) zasugerował potrzebę dokonania zmian w regulaminie Sądu Najwyższego, ponieważ nie reguluje on kwestii proceduralnych dotyczących wyrażenia opinii o projektach ustawodawstwa przez sędziów Sądu Najwyższego. 
Profesor zw. dr hab. Jerzy Jaskiernia (Uniwersytet Jana Kochanowskiego w Kielcach) podjął wątek relacji zadań i kompetencji prezydenta RP na kanwie sprawy rozstrzyganej przez Trybunał Konstytucyjny pod sygn. Kpt 2/08. Wyraził m.in. pogląd, że zadania prezydenta RP są punktem wyjściowym do jego kompetencji, jednocześnie podstawą działań prezydenta są kompetencje. Profesor podjął wątek punktu odniesienia dla ustalania niewyartykułowanych kompetencji prezydenta.

Profesor zw. dr hab. Mirosław Granat (Uniwersytet Kardynała Stefana Wyszyńskiego w Warszawie) pokreślił natomiast relacje pomiędzy przepisem prawnym a normą prawną, akcentując jednocześnie, że nie każda norma prawna stanowi zasadę prawa. Profesor zwrócił także uwagę na pojęcie „zupełności normatywnej Konstytucji” i „pojemności normatywnej Konstytucji”, wskazując, że są to kategorie, które wzajemnie się pokrywają. Profesor M. Granat odniósł się także sceptycznie do postulatów jurydyzacji partii politycznych i frakcji parlamentarnych partii politycznych.

Prezes Trybunału Konstytucyjnego prof. zw. dr hab. Andrzej Rzepliński zgłosił potrzebę wypracowania zasad tworzenia dobrego prawa w oparciu o doświadczenia i wiedzę zespołów eksperckich. Opowiedział się także za uznaniem aktywnej roli prezydenta w zakresie jego „czuwania nad przestrzeganiem Konstytucji”, która winna być ukierunkowana na przestrzeganie zasad państwa prawnego i państwa demokratycznego oraz praw i wolności człowieka i obywatela.

Profesor zw. dr hab. Paweł Sarnecki (Uniwersytet Jagielloński w Krakowie) zwrócił zaś uwagę na kwestię wydobywania z Konstytucji niewyartykułowanych kompetencji prezydenta RP (zarówno w drodze wykładni doktrynalnej, jak i poprzez wykładnię Trybunału Konstytucyjnego). Profesor przedstawił istotę tzw. kompetencji pochodnych (od prerogatyw). Zasygnalizował także możliwość poszukiwania kompetencji prezydenta RP nie tylko w Konstytucji, ale też w kompleksach ustaw. Profesor P. Sarnecki pozytywnie odniósł się do „twórczego” odczytywania przepisów Konstytucji przez Trybunał Konstytucyjny. W opinii profesora każdy organ konstytucyjny, w tym także prezydent, jest obowiązany nie tylko do przestrzegania Konstytucji, ale może także zajmować stanowisko w kwestii jej przestrzegania.

Profesor zw. dr hab. Andrzej Bałaban (Uniwersytet Szczeciński) opowiedział się natomiast przeciwko przyznaniu prawnego znaczenia pojęciu 
„funkcji”. Jego zdaniem jest to kategoria doktrynalna, ponieważ podstawą kompetencji jest konkretny przepis (przepisy), ale nie funkcja. W odniesieniu do problematyki zmian Konstytucji RP profesor wskazał m.in. na walor stabilności prawa, uznając, zmian należy dokonywać w niezbędnym zakresie i wyłącznie w sytuacjach konieczności. Postulował jednocześnie potrzebę dokonania pewnych korekt w Konstytucji RP polegających na wyartykułowaniu niektórych składników zasady państwa prawnego. Profesor A. Bałaban opowiedział się przeciwko uznawaniu prawa unijnego za część krajowego porządku prawnego, a projektowany jako nowelizacja Konstytucji tzw. rozdział europejski ocenił jako zbędny. Sformułował też kilka postulatów korekt w odniesieniu do regulacji prawa.

Następnie głos w dyskusji zabrał dr Ryszard Grodzicki (Uniwersytet Warszawski), który stwierdził wadliwość sposobu interpretowania art. 2 Konstytucji RP wobec faktu, że często nie uwzględnia on przesłanki (wytycznej) o „urzeczywistniania zasad sprawiedliwości społecznej”. Dr R. Grodzicki sceptycznie odniósł się do dekonstytucjonalizacji urzędu rzecznika prawa dziecka. Wskazał natomiast na dwa zasadnicze problemy związane z działalnością kontrolną Najwyższej Izby Kontroli, a mianowicie: brak możliwości badania działań przez organy samorządu terytorialnego przy uwzględnieniu kryterium celowości oraz brak możliwości kontroli takich czynności sądu, które nie mają klasycznie orzeczniczego charakteru, a są raczej zbliżone do czynności typu gospodarczego (jak np. kontrola i zatwierdzanie działań syndyka masy upadłościowej). Poddał pod rozwagę wprowadzenie ustaw organicznych w Polsce (np. w odniesieniu do kodeksów).

Natomiast prof. UJ dr hab. Piotr Tuleja (Uniwersytet Jagielloński) podniósł kwestię potencjalnego istnienia w Konstytucji RP tzw. klauzul wieczystych (tj. postanowień konstytucji, które nie mogą być zmieniane w trybie nowelizacji). Ponadto profesor wskazał inny problem z obszaru materii konstytucyjnej, a mianowicie: czy dopuszczalne byłoby ograniczanie przez ustawodawcę wykonywania określonych prerogatyw przez prezydenta. Profesor zasygnalizował, że zasadnicza przyczyna niewypracowania mechanizmu współdziałania pomiędzy prezydentem a prezesem Rady Ministrów wynika z brzmienia przepisów Konstytucji RP.

Mgr Beata Stępień-Załucka (Uniwersytet Rzeszowski) wypowiedziała się w przedmiocie ewentualnych zmian dotyczących Trybunału Stanu 
(np. w zakresie składu Trybunału czy kwestii proceduralnych w Trybunale). Wskazała także na polityczny kontekst powstania Trybunału Stanu.

Prof. UŁ dr hab. Krzysztof Skotnicki (Uniwersytet Łódzki) zwrócił natomiast uwagę na te obszary polskiej materii konstytucyjnej, które nie wymagają zmian. Ponadto sformułował pogląd o deprecjonowaniu znaczenia zasady społeczeństwa obywatelskiego wskutek nieprecyzyjności przepisów oraz niewłaściwej praktyki ich stosowania (np. zakresie obywatelskiej inicjatywy ustawodawczej). Profesor zgłosił także postulaty zmian konstytucyjnych w odniesieniu do instytucji referendum.

Prof. UŚ dr hab. Anna Łabno (Uniwersytet Śląski w Katowicach) krytycznie wypowiedziała się w przedmiocie konieczności dookreślania (tj. konstytucjonalizacji) tych zasad, które zostały wyinterpretowane przez Trybunał Konstytucyjny z przepisów Konstytucji RP. Swoje stanowisko prof. A. Łabno poparła m.in. argumentem obawy o trafne wskazanie granic tego dookreślania.

\section{III.}

Drugiej sesji Zjazdu Katedr, zatytułowanej Przeobrażenia konstytucyjne w Europie Zachodniej, przewodniczyła prof. zw. dr hab. Ewa Gdulewicz (Uniwersytet Marii Curie-Skłodowskiej w Lublinie).

W tej części swój referat Reformy ustrojowe w Zjednoczonym Królestwie w pierwszej dekadzie XXI wieku wygłosił dr hab. Piotr Mikuli (Uniwersytet Jagielloński w Krakowie). Na wstępie swoich rozważań stwierdził on, że wskutek różnych czynników, w tym również związanych z członkostwem w Unii Europejskiej, ustrój brytyjski podlega ciągłej ewolucji i coraz bardziej upodabnia się do ustrojów kontynentalnych. Stwierdził, że prawo powszechne (common law) doznaje silnej erozji, a coraz więcej regulacji wynika z prawa stanowionego. Zwrócił także uwagę na charakterystyczny dla Wielkiej Brytanii proces stosowanej przez sądy wykładni i argumentacyjny model stosowania prawa stanowionego. Profesor P. Mikuli podkreślił, że zasadniczymi podstawami zmian funkcjonowania brytyjskiego ustroju stały się ustawa o prawach człowieka z 1998 r. (Human Rights Act), która w istocie tworzy namiastkę konstytucji pisanej $\mathrm{w}$ znaczeniu formalnym, oraz proces dewolucji kompetencji. W dalszej części referatu profesor. P. Mikuli zaprezentował najważniejsze re- 
formy ustrojowe Zjednoczonego Królestwa przeprowadzone w XXI w. Stwierdził ponadto, że w odniesieniu do ustroju brytyjskiego można mówić o swoistej federalizacji (asymetrycznej), natomiast regionalizacja, pomimo iż została przeprowadzona, to w praktyce nie funkcjonuje.

Kolejny referat, zatytułowany Zakres reform konstytucyjnych we Francji w początkach XXI wieku, został wygłoszony przez prof. zw. dr. hab. Mirosława Granata (Uniwersytet Kardynała Stefana Wyszyńskiego w Warszawie). Profesor M. Granat analizował w nim zwłaszcza zakres dokonanej w lipcu 2008 r. reformy konstytucyjnego ustroju V Republiki. Zasadniczym wątkiem wystąpienia była próba rozstrzygnięcia kwestii, czy wobec wyjątkowo szerokiego zakresu tej nowelizacji nie można mówić wręcz o nowej konstytucji. W ocenie prof. M. Granata wskutek reform z lipca 2008 r. nie nastąpiła zmiana w aspekcie nierównowagi władzy we Francji, ponieważ nadal kluczową rolę odgrywa egzekutywa. Profesor uznał dokonane zmiany Konstytucji z 1958 r. jako zasadne i wskazał, że nowelizacja art. 62 (możliwość określania przez Radę Konstytucyjną skutków jej orzeczeń) stanowi wyraz odwagi ustrojodawcy i mogłaby być przeanalizowana w odniesieniu do polskiego Trybunału Konstytucyjnego. Profesor podkreślił także, że istotnym uzupełnieniem dokonanych reform konstytucyjnych są ustawy organiczne.

$\mathrm{W}$ niezwykle interesującej dyskusji podniesiono wiele istotnych problemów i zgłoszono szereg uwag oraz pytań do referentów.

Wypowiedź profesor Ewy Gdulewicz dotyczyła kwestii istnienia swoistego rodzaju regionalizacji asymetrycznej w ramach brytyjskiego ustroju konstytucyjnego. Profesor odniosła się także do oceny skutków dewolucji, jaki może powodować, np. federalizację państwa. Kolejna kwestia, którą poruszyła profesor E. Gdulewicz, dotyczyła oceny regulacji reformy konstytucyjnej z 2008 r. we Francji i jej zasadniczych skutków.

Prof. zw. dr hab. Jan Wawrzyniak (Akademia Leona Koźmińskiego) zwrócił m.in. uwagę na istnienie konwenansu konstytucyjnego, zgodnie z którym, gdy jedna z partii zamierza zmienić konstytucję (w sensie materialnym, tj. uchwalić ustawę nowelizującą ustrój konstytucyjny państwa), to w swoim programie wyborczym powinna to uprzednio zapowiedzieć. Profesor dotknął istotnej kwestii, a mianowicie, czy taki konwenans nie stanowi utrudnienia dla uchwalenia ustawy zmieniającej ustrój konstytucyjny i w rezultacie czy tzw. elastyczność konstytucji nadal jest jedną z jej głównych cech. 
Profesor P. Sarnecki wypowiedział się w przedmiocie procesu regionalizacji w Anglii, który po okresie wstrzymania został ponownie przywrócony.

Prof. Andrzej Rzepliński podkreślił rolę prezydenta Republiki Francuskiej jako „zwornika” systemu rządów. W swojej wypowiedzi Profesor dotknął także kwestii stopnia zainteresowania Autorów obcojęzycznych ustrojem Rzeczypospolitej Polskiej.

Dr Jacek Mazur (Najwyższa Izba Kontroli) podniósł inny jeszcze wątek w związku z referatem prof. M. Granata. Mianowicie wskazał na istotę ewaluacji, tj. oceny realizacji polityk publicznych we Francji, która jest odrębnym instrumentem od oceny działalności rządu. Dr J. Mazur sformułował tezę, iż ewaluacja może służyć funkcji kontrolnej, ale również funkcji ustawodawczej. Ponadto zwrócił uwagę, że konstytucja powierza ewaluację Trybunałowi Obrachunkowemu, co podkreśla równy dystans między Trybunałem Obrachunkowym a parlamentem i rządem. Zdaniem dr. J. Mazura można sformułować tezę, że ewaluacje są skierowane na sprawy i obywateli i na sprawy społeczne.

Były prezes Trybunał Konstytucyjnego dr Bohdan Zdziennicki (Wyższa Szkoła Zarządzania i Prawa im. Heleny Chodkowskiej) zwrócił uwagę na praktykę Trybunału Konstytucyjnego, która w ogólnym ujęciu polega na kontroli konstytucyjności prawa, ale dotyczy także relacji pomiędzy celami, zasadami i wartościami a obowiązującym prawem. Podkreślił m.in. znaczenie badań prawnoporównawczych w stosunku do poznawczych celów naukowych, zwracając uwagę na ich inspirujące znaczenie w określaniu potrzeb nowelizacji obowiązującej Konstytucji RP.

Dr Krzysztof Urbaniak (Uniwersytet im. Adama Mickiewicza w Poznaniu) odniósł się do reformy władzy sądowniczej w Wielkiej Brytanii, oceniając, że obok reformy dewolucyjnej miała ona najbardziej kompleksowy charakter. Jednocześnie, jak zauważył, przemianom podlegały także regulacje odnośnie do władzy ustawodawczej (w tym także reformy prawa wyborczego) i władzy wykonawczej.

Dr Katarzyna Kubuj (Instytut Nauk Prawnych PAN) zwróciła natomiast uwagę na zakres zmian Konstytucji V Republiki, podkreślając, że w gruncie rzeczy najbardziej daleki proces zmian obejmuje ostatnie dwudziestolecie oraz, że większość dokonanych zmian dotyczyła spraw unijnych (sensu largo). Wskazując instytucję kontroli konstytucyjności przepisów ustaw w try- 
bie kontroli następczej z inicjatywy obywateli, podkreśliła wpływ ustaw organicznych na konstrukcję ustroju konstytucyjnego.

Profesor dr hab. Andrzej Zięba (Uniwersytet Jagielloński w Krakowie) przypomniał, że podmiotem inicjującym zmiany konstytucyjne w Wielkiej Brytanii była Partia Pracy, która aż do początków lat osiemdziesiątych XX w. nie miała programowo rozwiniętej warstwy ustrojowej. Profesor wskazał, że na początku lat dziewięćdziesiątych partia pracy zaczęła uwzględniać w swojej doktrynie problematykę wolności i praw obywatelskich, co między innymi zaskutkowało uchwaleniem ustawy o prawach człowieka. W konkluzji swojego wystąpienia profesor stwierdził, istnieją określone materie prawnoustrojowe, które wymagają wsparcia poprzez materie politycznoustrojowe, natomiast kwestia konkretnych regulacji oraz procedur ich wprowadzenia stanowi odrębną kwestię.

IV.

Sesja trzecia dotyczyła Przeobrażeń konstytucyjnych w państwach Europy $i$ Wschodniej. Moderatorem była prof. nadzw. dr hab. Anna Łabno (Uniwersytet Śląski w Katowicach).

Referat wygłaszał dr Witold Brodziński (Uniwersytet Łódzki): Nowa konstytucja Republiki Węierskiej. Na wstępie swojego wystąpienia referent podkreślił, że Węgry były jedynym europejskim państwem, w którym po upadku rządów komunistycznych w 1990 r. nie uchwalono nowej konstytucji. Obowiązywała konstytucja, której geneza sięgała roku 1949. Referent zaprezentował przeobrażenia ustrojowe na Węgrzech w XX w. Główny akcent położył na zagadnienia aksjologii obowiązującej ustawy zasadniczej z dnia 25 kwietnia 2011 r. Zwrócił także m.in. uwagę na: rzadko spotykaną systematykę ustawy zasadniczej; odmienną strukturę wewnętrzną poszczególnych części konstytucji; fakt, iż akt ten zawiera treści doniosłe normatywnie, treści ideologiczne i historyczne; obszerność preambuły. Ponadto - jak zauważył - twórcy Konstytucji z 2011 r. niezwykle stanowczo podkreślają chrześcijańskie korzenie Węgier. Nowa Konstytucja ustanawia nie tylko podstawę porządku prawnego Węgier, ma także wymiar ideologiczny. Poza tym Konstytucja przywróciła tradycyjną nazwę państwa - Węgry. Następ- 
nie dr W. Brodziński dokonał analizy ustawy zasadniczej Węgier pod kątem materialnym i omówił m.in. podstawowe zasady określające funkcjonowanie organów państwowych oraz system prawa.

Problematyka zamykająca ostatnią sesję 54. Zjazdu Katedr dotyczyła ustroju Ukrainy. Referat pt. Przemiany konstytucyjne na Ukrainie wygłosił dr Artur Olechno (Uniwersytet w Białymstoku). Omówił on historyczny kontekst uchwalenia Konstytucji z 1996 r. Wskazał, proklamowała ona republikę o ustroju prezydencko-parlamentarnym, oraz jej najbardziej kluczowe postanowienia. Scharakteryzował nowelizację Konstytucji Ukrainy z dnia 8 grudnia 2004 r., która generalnie zawężała kompetencje prezydenta. Podkreślił także znaczenie orzeczenia Sądu Konstytucyjnego Ukrainy z dnia 30 września 2010 r., które - ze względu na niekonstytucyjny tryb uchwalenia uchyliło wspomnianą nowelizację z 2004 r., przywracając w ten sposób treść Konstytucji z 1996 r. Dr A. Olechno zaprezentował także wiele praktycznych aspektów stosowania przepisów konstytucyjnych na Ukrainie.

Po przedstawionych referatach odbyła się bardzo ciekawa dyskusja dotycząca zwłaszcza ustrojów Węgier i Ukrainy, która zainspirowała także do refleksji nad ustrojem Rzeczypospolitej Polskiej.

Dr Jacek Mazur wypowiedział się w kwestii konieczności popularyzacji systemów ustrojowych państw Europy. Za szczególnie istotne uznał w tym kontekście podejmowanie analiz prawnoporównawczych przez przedstawicieli polskiej doktryny prawa konstytucyjnego. Dr J. Mazur wypowiedział się także o Państwowej Izbie Obrachunkowej Węgier (najwyższym organie kontroli na Węgrzech), w tym m.in. w kontekście dokonanej w 2011 r. zmiany ustawowej, która określiła nową strukturę wewnętrzną Izby.

Dr Piotr Uziębło (Uniwersytet Gdański) zwrócił uwagę, że istnieją wspólne cechy ustrojów Węgier i Ukrainy. Podkreślił mianowicie kluczową rolę ustaw organicznych w określaniu ustroju konstytucyjnego Węgier. W odniesieniu do Ukrainy dr P. Uziębło podkreślił rozwarstwienie sfery prawnej i praktycznej Konstytucji Ukrainy.

Głos w dyskusji zabrał także profesor Marian Grzybowski, który podzielił pogląd o konieczności wymiany doświadczeń wynikających z praktyki stosowania konstytucji pomiędzy Polską a państwami sąsiednimi, ponieważ mogłoby to być podstawą dokonywania korekt przepisów konstytucyjnych. Profesor $\mathrm{z}$ aprobatą odniósł się do kwestii konstytucjonalizacji prokuratury, a w szcze- 
gólności takich zagadnień, które dotyczą określenia statusu prokuratora generalnego (i np. jego racji z Sejmem). W odniesieniu do idei tzw. otwartego rządu profesor zwrócił uwagę, że kwestia relacji pomiędzy czynnikiem profesjonalnym a czynnikiem społecznym i jego wpływem na decyzje państwowe powinna zostać poddana dyskusji. Profesor zaakcentował też inny problem, a mianowicie określenia granic instrumentalizacji konstytucji.

Prof. UŁ dr hab. Krzysztof Skotnicki wskazał na poznawcze walory płynące $z$ analiz sfery normatywnej i praktyki konstytucyjnej państw Europy. Odwołał się w związku z tym do szczegółowych uregulowań obywatelskiej inicjatywy ustawodawczej na prof. UŚ dr hab. Anna Łabno poruszyła bardzo istotny problem kryteriów oceny dla kierunku przeobrażeń ustrojowych na Węgrzech.

Po zakończeniu ostatniej sesji prof. UwB dr hab. Stanisław Bożyk dokonał podsumowania Zjazdu. Wyraził radość ze wspólnego spotkania, zorganizowanego przez Katedrę Prawa Konstytucyjnego Uniwersytetu w Białymstoku. Zaznaczył, że materiały ze Zjazdu zostaną opublikowane. Podziękował wszystkim za udział, wyrażając nadzieję, że będą wspominać Zjazd jako owocny i przyjemny, ponieważ spotkanie w pięknym Augustowie stworzyło także możliwość wypoczynku w przerwach pomiędzy poszczególnymi częściami merytorycznymi. Następnie profesor ogłosił zamknięcie 54. Zjazdu Katedr i Zakładów Prawa Konstytucyjnego.

V.

W trakcie Zjazdu Katedr tradycyjnie odbyło się Zebranie Polskiego Towarzystwa Prawa Konstytucyjnego, a także Zebranie Kierowników Katedr i Zakładów Prawa Konstytucyjnego. Podczas uroczystej kolacji ogłoszono, że organizatorem kolejnego Zjazdu Katedr i Zakładów Prawa Konstytucyjnego będzie Katedra Prawa Konstytucyjnego Wydziału Prawa i Administracji Uniwersytetu Mikołaja Kopernika w Toruniu, kierowana przez prof. zw. dr. hab. Zbigniewa Witkowskiego.

Lech Andrzej Jamróz (Uniwersytet w Białymstoku) 